\title{
Microbiological Quality of Fish and Shellfish, with Special Reference to Vibrio parahaemolyticus in Domestic Markets of West Bengal, India
}

\author{
Chandraval Dutta ${ }^{1 *}$, Sanjib Kumar Manna ${ }^{2}$, Ashis Kumar Panigrahi ${ }^{1}$ and \\ Chandan Sengupta ${ }^{3}$
}

${ }^{1}$ Department of Zoology, University of Kalyani, Kalyani, Nadia-741235, West Bengal, India

${ }^{2}$ ICAR-Central Inland Fisheries Research Institute, Barrackpore-700 120, West Bengal, India

${ }^{3}$ Microbiology Laboratory, Department of Botany, University of Kalyani, Kalyani, Nadia-741235, West Bengal, India

*Corresponding author

\begin{abstract}
A B S T R A C T
We studied the microbiological quality and prevalence of Vibrio parahaemolyticus in finfish and shellfish sold in the domestic markets of West Bengal, India following

Keywords

Vibrio

parahaemolyticus,

Penaeus monodon,

Setipinnaphasa

Article Info

Accepted:

20 September 2018

Available Online:

10 October 2018 enrichment in alkaline peptone water and further plating on to thiosulfate citrate bile salt sucrose agar. Total plate count of bacteria in shrimp flesh with the exoskeleton, and finfish muscle with skin was also estimated which ranged from $20 \pm 1.12 \times 10^{5} \mathrm{cfu} / \mathrm{g}$ to $73 \pm 1.12 \times$ $10^{5} \mathrm{cfu} / \mathrm{g}$, and from $0.2 \pm 0.18 \times 10^{5} \mathrm{cfu} / \mathrm{g}$ to $1.2 \pm 0.43 \times 10^{5} \mathrm{cfu} / \mathrm{g}$, respectively. Prevalence of $V$. parahaemolyticus varied in different fish and shellfish species, with highest prevalence in Lutjanus sp (27.77\%) and lowest in Setipinnaphasa (10\%); the bacterium was not detected in Labeobata and Channastriata. The contamination rate was higher in shellfish like Penaeus monodon (42.85\%) and P. indicus (40\%).Contamination was higher during summer than in winter: an average of $20.85 \%$ of finfish and shellfish were contaminated during winter, compared to contamination of $31.45 \%$ of samples during summer months. The study showed that although overall microbial load was within permissible limits, fish and shellfish were contaminated with V. parahaemolyticus raising food safety concern to the domestic consumers.
\end{abstract}

\section{Practical application/ significance of the study}

Fish and shellfish are known to transmit many of the established food borne microbial infections and intoxications to human. India has meager information available on the occurrence of food contamination by pathogenic bacteria especially in domestic markets. The present study has given an indication of a hygienic sanitary quality of finfishes and shellfishes available in domestic markets of West Bengal.

Wide occurrence of $V$. parahaemolyticus in raw fish and shrimps may pose a serious health risk for large fish-eating population of Bengal. Data on the uneven distribution of this bacterium in various fish and shellfish will provide a guideline for microbial safety of 
different fish and shellfishes as well as fish processing industry towards better food safety.

\section{Introduction}

The microbiological quality of finfish and shellfish is important for consumer health. Both the total bacterial load and presence of pathogens determine quality and safety of fish/fish products. Seafood often harbors infectious agents that are naturally present in the aquatic environment or may be introduced through human intervention. Raw or undercooked seafood have been implicated as major vehicles of Vibrio parahaemolyticus infection to humans (Venkitanarayanan and Doyle, 2001). Vibrio parahaemolyticus, ahalophilic gram-negative bacterium is widely distributed in temperate and tropical coastal waters throughout the world (DePaola et al., 2000) and some of its strains can cause gastroenteritis in humans through ingestion of contaminated seafood (Matsumoto et al., 2000 ; Zarei et al., 2012 ; Yano et al., 2014). Seafood mainly crustaceans \& mollusksare generally considered as reservoirs of this pathogen (Cook et al., 2000; DePaola et al., 2000; Daniels et al., 2001; Lozano-Leon et al., 2003). In different environmental conditions, this bacterium could thrive and proliferate in oysters (Gooch et al., 2002). V. parahaemolyticus infection has been implicated as one of the major causes of foodborne illness in the world (Joseph et al., 1983; Wong et al., 2000) and in Asia (Chiou et al., 2000; Chowdhury et al., 2013; Kubota et al., 2008; Ma et al., 2014). Majority of the food poisoning cases have been reported due to $V$. parahaemolyticus infection in Taiwan, Japan, and several Southeast Asian countries (Chiou et al., 1991)

West Bengal is a major fish producing as well as fish eating state in India where large majority of people eat fish. The state requires approximately 1.672 million tonnes fish per annum. During 2014-15, the state produced 1.617 million tonnes fish of which 1.438 million tonnes from Inland and 0.179 million tonnes from Marine sector. West Bengal also has the largest impounded brackish water area where traditional and improved traditional shrimp farming are practiced. The total shrimp production in West Bengal was 115916 ton during 2014-15 (Department of Fisheries, Govt. of West Bengal 2014-15).

Unlike in developed countries, Indians prefer deep fried or boiled curry preparations of fish $\&$ seafood which markedly reduce microbial load, including $V$. parahaemolyticus in cooked foods. Despite this, prevalence of $V$. parahaemolyticus in human diarrhea cases in India has also been noticed by several researchers. In India, the first outbreak of Vibrio parahaemolyticus induced diarrhea in human was reported from Vellore in South India (Lalitha et al., 1983). West Bengal, Kolkata and neighboring Bangladesh are well known for cholera and other endemic diarrhoeal outbreaks. Pal et al., 1985 have reported about $3.5-23.9 \%$ of acute human diarrhea cases owing to Vibrio parahaemolyticus infection in Kolkata. During 2001-2012 V. parahaemolyticus has been isolated from $1.308 \%$ of diarrheal patients admitted at Infectious Disease Hospital, Kolkata (Pazhani et al., 2014). V.parahaemolyticus diarrhea incident rate was $0.63 \%$ reported and isolated by Kanungo et al., (2012) from urban slum in Kolkata during 2007-2010.

West Bengal is one of the major inland fish producing states, producing approximately 21$23 \%$ of inland fish production of India. Export of marine and aquaculture product from West Bengal for the year 2014-15 was 85138 ton, valued 609.05 Million US\$.(Department of Fisheries, Govt. of West Bengal 2014-15). Fish and shellfish going for export are processed that reduces their microbial load. 
However, bulk fish and shellfish produce go into domestic markets without any processing that make them vulnerable to microbial contamination and poor quality. However, microbial quality of fish and shellfish sold in domestic markets are not routinely monitored. The present study has examined the microbiological safety of finfish and shellfish in domestic markets and prevalence of Vibrio parahaemolyticus in said samples from different retail fish markets in and around Kolkata

\section{Materials and Methods}

\section{Finfish and shellfish collection}

Fresh but ice preserved finfish species like Latescalcarifer, Mugil cephalus, Channastriata, Channa punctata, Labeobata, Gudusia chapra, Pampus argenteus, Lutjanussp., Setipinna phasa and shrimps viz. Penaeus monodon, Penaeus indicus were collected aseptically in individual polypacks from domestic retail markets in and around Kolkata, West Bengal, India and brought to the laboratory on ice.

\section{Total plate count of bacteria}

Shrimp muscles including exoskeleton and finfish flesh were cut into small pieces aseptically with sterile scissors and homogenized in sterile normal saline $(0.85 \%$ $\mathrm{NaCl})$ to $10 \% \mathrm{w} / \mathrm{v}$ suspension. The homogenized tissue samples were then serially diluted in normal saline and plated onto nutrient agar (DIFCO, USA) by pour plate technique for total aerobic plate count (TPC) of bacteria and incubated at $37^{\circ} \mathrm{Cfor} 24$ hours in a bacteriological incubator.

Ice is widely used for fish preservation, but commercially produced ice may be a source of bacterial contamination to the produce. To examine microbiological quality, ice samples were collected aseptically from ice sellers in fish markets in sterile poly packs and $10 \mathrm{ml}$ of ice sample was inoculated in $90 \mathrm{ml}$ normal saline $(0.85 \% \mathrm{NaCl})$ to $10 \% \mathrm{w} / \mathrm{v}$ suspension, serially diluted in normal saline and plated on to nutrient agar (DIFCO, USA) by pour plate technique for total aerobic plate count (TPC) of bacteria.

\section{Isolation of $V$. parahaemolyticus}

The procedure described by Food and Drug Administration (FDA, 2004) was followed with minor modifications for estimation of Vibrio parahaemolyticus in fish and shellfish samples. Briefly, $25 \mathrm{~g}$ sample was homogenized in $225 \mathrm{ml}$ alkaline peptone water (APW) (DIFCO, USA) and an aliquot was taken for making serial dilution and spread plating on TCBS agar (DIFCO, USA) plates. The enrichment broth was incubated at $37^{\circ} \mathrm{C}$ for $6 \mathrm{~h}$ and subcultured on TCBS agar. The TCBS agar plates were incubated at $37^{\circ} \mathrm{C}$ for 24 h. Presumptive Vibrio parahaemolyticus colonies having bluish-green color on TCBS agar plates were picked and identified by biochemical tests, viz. Oxidase test, sensitivity to $\mathrm{O} / 129$, growth in $\mathrm{NaCl}(1 \%, 3 \%, 6 \%, 8 \%$ and $10 \%$, acid production from sucrose, dcellobiose, lactose, arabinose and d-mannose, gelatinase and production of ornithine and lysine decarboxylase and arginine dihydrolases per the protocol recommended in the FDA Bacteriological Analytical Manual (FDA, 2004).

\section{Identification of Vibrio parahaemolyticus isolates}

The gene encoding 16S rDNA was PCR amplified from the presumptive Vibrio parahaemolyticus using universal bacterial $27 \mathrm{f}$ (5'-GAG TTT GAT CCT GGC TCA G-3') and 1492r (5'- TAC GGT TAC CTT GTT ACG AC-3') primers. The PCR reaction was performed in $50 \mu \mathrm{l}$ volume containing $25 \mu \mathrm{l}$ of 
Red TaqReadyMix (Sigma), $22 \mu 1$ water, $0.2 \mu$ each of forward and reverse primers and template DNA. The template DNA was obtained by extracting genomic DNA using the Gen Elute Bacterial Genomic DNA Kit (Sigma- Aldrich) from a fresh colony grown on nutrient agar. The following cycle was used for PCR reaction: initial denaturation at $95^{\circ} \mathrm{C}$ for 1 minute, followed by 35 cycles at $95^{\circ} \mathrm{C}$ for 30 seconds, $55^{\circ} \mathrm{C}$ for 30 seconds, $72^{\circ} \mathrm{C}$ for 2 minutes and the final extension at $72^{\circ} \mathrm{C}$ for 5 minutes. The PCR amplicons were analyzed on a $1 \%$ agarose gel with $0.5 \mathrm{X}$ TBE as the running buffer. A 100 bp standard DNA ladder (Sigma) was included on each gel for base pair size comparison (Figure 1). PCR products were sequenced from a commercial house by Sanger sequencing method. Sequenced data were edited and aligned using Codon Code Software and identification of isolates were determined following sequence homology in NCBI GenBank and RDP databases. The phylogenic relationship among the strains B2, B3, B4, B6 and B11 was determined with the closest type strains using MEGA (version 5.2) software following the minimum evolution method.

\section{Statistical analysis}

The bacterial loads in finfish and shellfish are expressed as mean + S.D and compared in different species using SAS 9.2 software at $\alpha$ $=0.05$ significance. The figures and graphs were drawn using JMP 8.0.2 software.

\section{Results and Discussion}

The total bacterial loads (cfu/g) in the muscle with the skin of finfish and shellfish in different domestic markets in and around Kolkata are presented in Table 1 . The total bacterial load of finfish varied from $0.2 \pm 0.18$ $\mathrm{x} 10^{5} \mathrm{cfu} / \mathrm{g}$ to $1.2 \pm 0.43 \times 10^{5} \mathrm{cfu} / \mathrm{g}$. The bacterial load of shrimp samples and ice varied from $20 \pm 1.12 \times 10^{5} \mathrm{cfu} / \mathrm{g}$ to $73 \pm 1.12 \times$
$10^{5} \mathrm{cfu} / \mathrm{g}$ and $0.3 \pm 0.03 \times 10^{5} \mathrm{cfu} / \mathrm{ml}$ to 1.0 $\pm 0.12 \times 10^{5} \mathrm{cfu} / \mathrm{ml}$ respectively. Bacterial load in fish, shellfish or ice samples collected from different markets did not differ significantly in their bacterial loads; however bacterial load in shellfish samples were significantly higher than that in fin fish and ice samples.

The presumptive $V$. parahaemolyticus isolates obtained from finfish and shellfish were identified by a battery of biochemical tests. However, a few isolates differ in one or two biochemical reactions recommended by FDA create confusion among researchers in the identification of the organism (Bharathi et al., 1987; Karunasagar et al., 1997). Hence, to confirm identification, 16S rDNA sequence was used for correct identification of the isolates. The 16SrDNA sequences of representative isolates were submitted to GenBank and accession numbers obtained (JQ265999, JQ266001, and JQ266003). Based on the nucleotide homology and phylogenetic analysis of the 16S rDNA gene sequences, identification of B2, B3, B4, B6 and B11 strains were confirmed as Vibrio parahaemolyticus. The strains B6 and B11 showed $100 \%$ similarity while isolate B2, B3, B4 showed 99\% similarity with Vibrio parahaemolyticus (Figure 2).

There were individual species variation among finfish and shellfish samples in their prevalence of Vibrio parahaemolyticus (Table 2). The bacterium was most commonly isolated from marine fishes, viz. Lutjanus sp (27.77\%), Pampus argentius (16.66 \%), estuarine fishes, viz. Lates calcarifer (21.42\%), Mugil cephalus (12.5\%), and less so in freshwater fishes, viz. Gadusia chapra (12.5\%), Channa puntatus (11.11\%), Setipinnaphasa (10\%). Overall the bacterium was detected in 51(25.5\%) samples. The contamination rate was higher in shellfish like Penaeus monodon (42.85\%) and Penaeus indicus (40\%). The distribution of $V$. 
parahaemolyticus in finfish and shell fishes of different months are presented in Figure 3. It was also observed that $V$. parahaemolyticus load was higher in warmer months viz. March, April than colder months December and January.

The present study was conducted to assess the microbiological quality of finfish and shellfish in and around Kolkata and their safety for domestic consumers. The total bacterial load in fish and shellfish samples collected from various retail markets of West Bengal, India showed insignificant variation $(\mathrm{P}>0.05)$ among retail market sites. Possible reason for this was that the markets surveyed were not very far from one another; source of the fish available in the markets might have originated from adjacent fish farms, bheries (low saline wetlands) and estuaries and within the same geo-climatic region. However, bacterial load in finfish, shrimp, and ice samples varied significantly $(\mathrm{P}<0.05)$ with the highest load in shellfish. The bacterial loads in fish samples of Bengal were within the range of $10^{4} \mathrm{cfu} / \mathrm{g}$. Thus, most of the finfish samples examined from different markets were of acceptable quality, considering the TPC limits set by the ICSMF (1986), USFDA, EU, and Export Inspection Council of India. The bacterial loads of shrimp were more or less same in different fish markets and were in the range of 2-7.3 x $10^{6} \mathrm{CFU} / \mathrm{g}$. As per ICSMF guidelines (1986) shrimp from different markets were also acceptable. An earlier study undertaken at farm level had reported APC of whole shrimp, shrimp surface and gut of the shrimp to be $8.40 \times 10^{5}, 4.60 \times 10^{5} / \mathrm{cm}^{2}$ and $1.26 \times 10^{6} / \mathrm{g}$ (Nayyarahamed et al., 1994). Moreover, the bacterial loads in ice samples were recorded in the range of $10^{3} \mathrm{cfu} / \mathrm{g}$ which showed insignificant variation for fish and shrimp contamination. The TPC of finfish and shellfish were found to be in conformity with the result as described by Manna et al., (2008). The bacterial loads in shrimps were higher than in fish samples, possibly as species variation or variation in microbiological quality of shrimp farms. In this region, the low to medium saline intensive shrimp farms are often contaminated with city sewage water to varying extents.

The present study also examined the prevalence of $V$. parahaemolyticus in finfish and shellfish collected from domestic markets in and around Kolkata. This organism was given importance as it is frequently implicated in diarrhoeal cases in human since 1996 and abruptly gained a new global dimension for its pathogenicity since (1997) (Okuda et al., 1997). V. parahaemolyticus in various species of finfish and shellfish were detected in 25.5\% of samples. The contamination rate was higher in shellfish ( $P$. monodon $42.85 \%$, $P$. indicus $40 \%)$ as compared to finfish (15.99\%). In Kolkata, the prevalence of $V$. parahaemolyticus was earlier reported from shellfish (45.83\%) and finfish (16.73\%) (Das et al., 2009). Out of 90 fish samples examined about 60 showed positive with V.parahaemolyticus containing virulence $t d h$ gene in Kolkata (Pal and Das 2010). The bacterium was most commonly isolated from marine fishes and less so in freshwater fishes. No $V$. parahaemolyticus was detected in Labeobata and Channastriata samples and might be considered safe for human consumption. $V$. parahaemolyticus could infect wide host range starting from marine animals, fish to fresh water fish. Fish irrespective of their origin (marine and fresh water) act as an ideal substrate for the proliferation of $V$. parahaemolyticus. Based on early ecological studies occurrences of $V$. parahaemolyticus have also recorded in freshwater plankton and in freshwater fishes. The occurrence of $V$. parahaemolyticus from market samples of freshwater fishes was might be due to cross-contamination and mishandling by fishmonger (Sarkar et al., 1985). 
Table.1 Bacterial load, [cfu/g or cfu/ml] in finfish, shellfish and ice samples

\begin{tabular}{|l|c|r|r|r|r|r|} 
& \multicolumn{6}{|c}{ Market } \\
\hline & Barrackpore & Garia & Howrah & Kolkata & Kalyani & Ranaghat \\
\hline Fish $^{\text {a }}$ & $0.8 \pm 0.34$ & $1.2 \pm 0.43$ & $0.7 \pm 0.64$ & $0.7 \pm 0.55$ & $0.6 \pm 0.28$ & $0.2 \pm 0.18$ \\
\hline Shrimp $^{\text {b }}$ & $54 \pm 2.01$ & $56 \pm 2.91$ & $73 \pm 1.12$ & $61 \pm 1.56$ & $27 \pm 1.34$ & $20 \pm 1.12$ \\
\hline Ice & $0.7 \pm 0.07$ & $0.9 \pm 0.11$ & $1.0 \pm 0.12$ & $0.8 \pm 0.10$ & $0.3 \pm 0.04$ & $0.3 \pm 0.03$ \\
\hline
\end{tabular}

${ }^{a}$ Fish (Labeo rohita, Labeo bata, Gudisia chapra etc.

${ }^{\mathrm{b}}$ Shrimps (Penaeus monodon, Penaeus indicus).

Bacterial load (Mean \pm S.D.) expressed as CFU x $10^{5} / \mathrm{g}$ fish or shellfish or CFU x $10^{5} / \mathrm{ml}$ ice; $\mathrm{n}=5$ for each fish/ shrimp species and ice samples from each market.

Table.2 Prevalence of $V$. parahaemolyticus in different finfish and shellfish species

\begin{tabular}{|c|c|c|c|c|}
\hline Fish /shellfish & $\begin{array}{l}\text { Habitat of the fish } \\
\text { / shellfish species }\end{array}$ & $\begin{array}{r}\text { Number of } \\
\text { samples } \\
\text { examined }\end{array}$ & $\begin{array}{r}\text { Number of } \\
\text { samples } \\
\text { contaminated }\end{array}$ & $\begin{array}{r}\text { Percentage of } \\
\text { samples } \\
\text { contaminated }\end{array}$ \\
\hline $\begin{array}{l}\text { Penaeus } \\
\text { monodon }\end{array}$ & Marine \& estuarine & 35 & 15 & $42.85 \%$ \\
\hline Penaeus indicus & Marine \& estuarine & 45 & 18 & $40 \%$ \\
\hline $\begin{array}{l}\text { Lutjanus Sp. } \\
\text { (Snapper) }\end{array}$ & $\begin{array}{l}\text { Marine \& coastal } \\
\text { water }\end{array}$ & 18 & 5 & $27.77 \%$ \\
\hline Setipinnaphasa & Rivers, estuaries & 10 & 01 & $10 \%$ \\
\hline Latescalacarifer & $\begin{array}{l}\text { Coastal water, } \\
\text { estuaries }\end{array}$ & 28 & 06 & $21.42 \%$ \\
\hline Mugil cephalus & $\begin{array}{l}\text { Coastal water, } \\
\text { estuaries }\end{array}$ & 8 & 01 & $12.5 \%$ \\
\hline $\begin{array}{l}\text { Pampus } \\
\text { argenteus }\end{array}$ & Marine \& costal & 12 & 02 & $16.66 \%$ \\
\hline Gudusia chapra & River, ponds & 16 & 02 & $12.5 \%$ \\
\hline Labeobata & Ponds, tanks, rivers & 12 & 0 & 0 \\
\hline $\begin{array}{l}\text { Channa } \\
\text { punctata }\end{array}$ & $\begin{array}{l}\text { Ponds, tank, flood } \\
\text { plain wetlands }\end{array}$ & 9 & 01 & $11.11 \%$ \\
\hline Channa striata & $\begin{array}{l}\text { Ponds, tanks, flood } \\
\text { plain wetlands }\end{array}$ & 7 & 0 & $0 \%$ \\
\hline Total & & 200 & 51 & $25.5 \%$ \\
\hline
\end{tabular}


Fig.1 Electrophoresis of 16S rDNA PCR products from Vibrio parahaemolyticus, isolated from fish and shell fish samples. Lane M - Molecular weight marker (Sigma),

Lane- 1 to 7 Vibrio parahaemolyticus

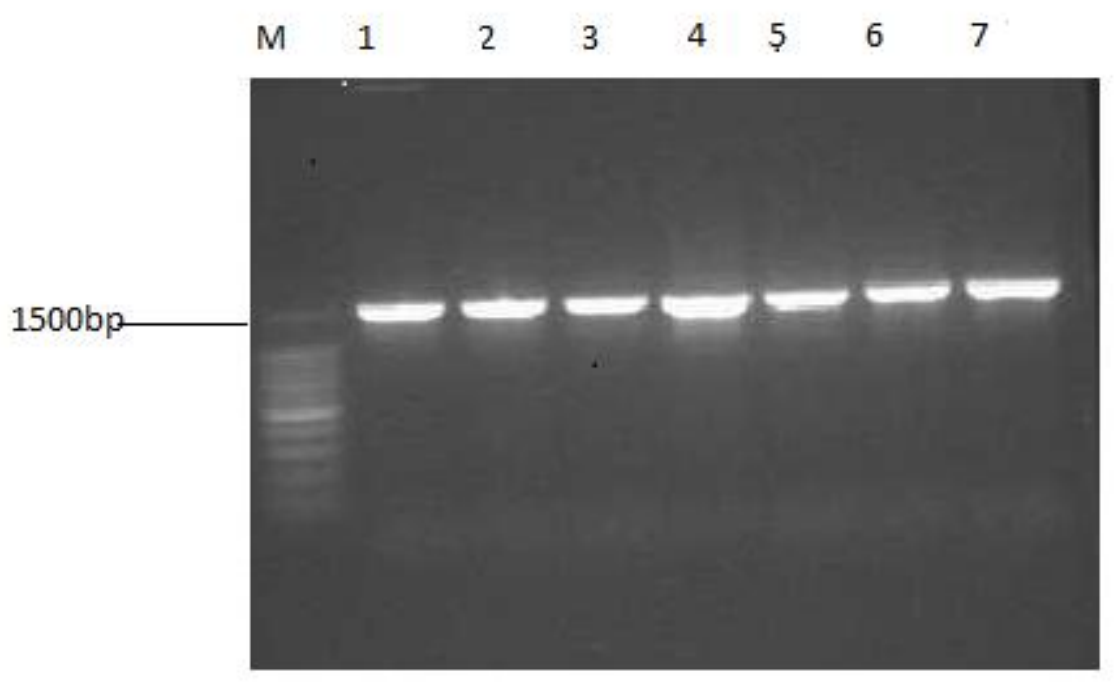

Fig.2 Phylogenetic tree showing the relationship of bacterial isolates (B2, B3, B4, B6 and B11 with type strains of Vibrio parahaemolyticus. B2 strain (KUHWB26)B3 strain (KUGWB43), B4 (KUBWB12), B6(KUBWB76)]

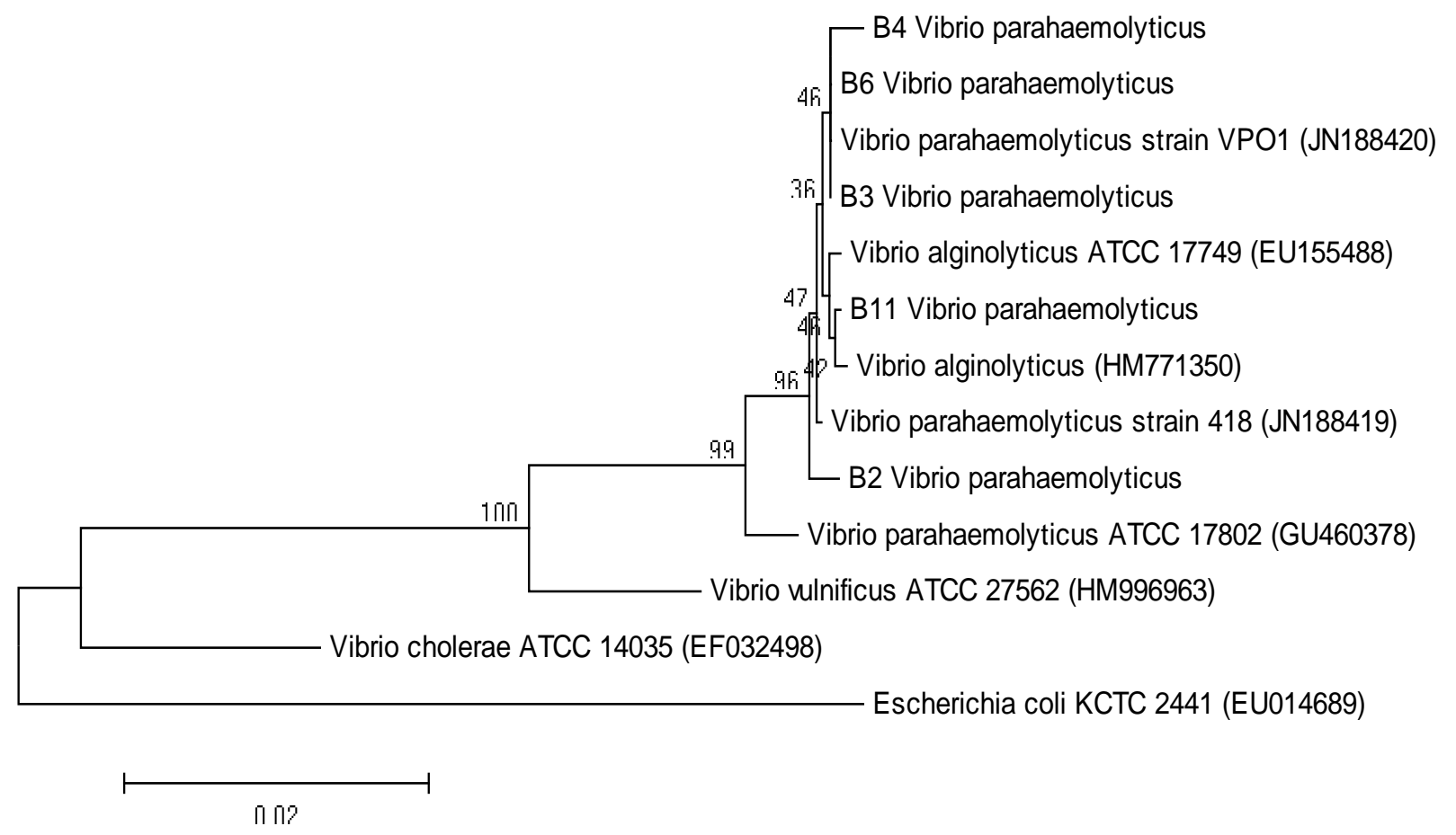


Fig.3 Prevalence of V. parahaemolyticus in fish and shellfishes in different months

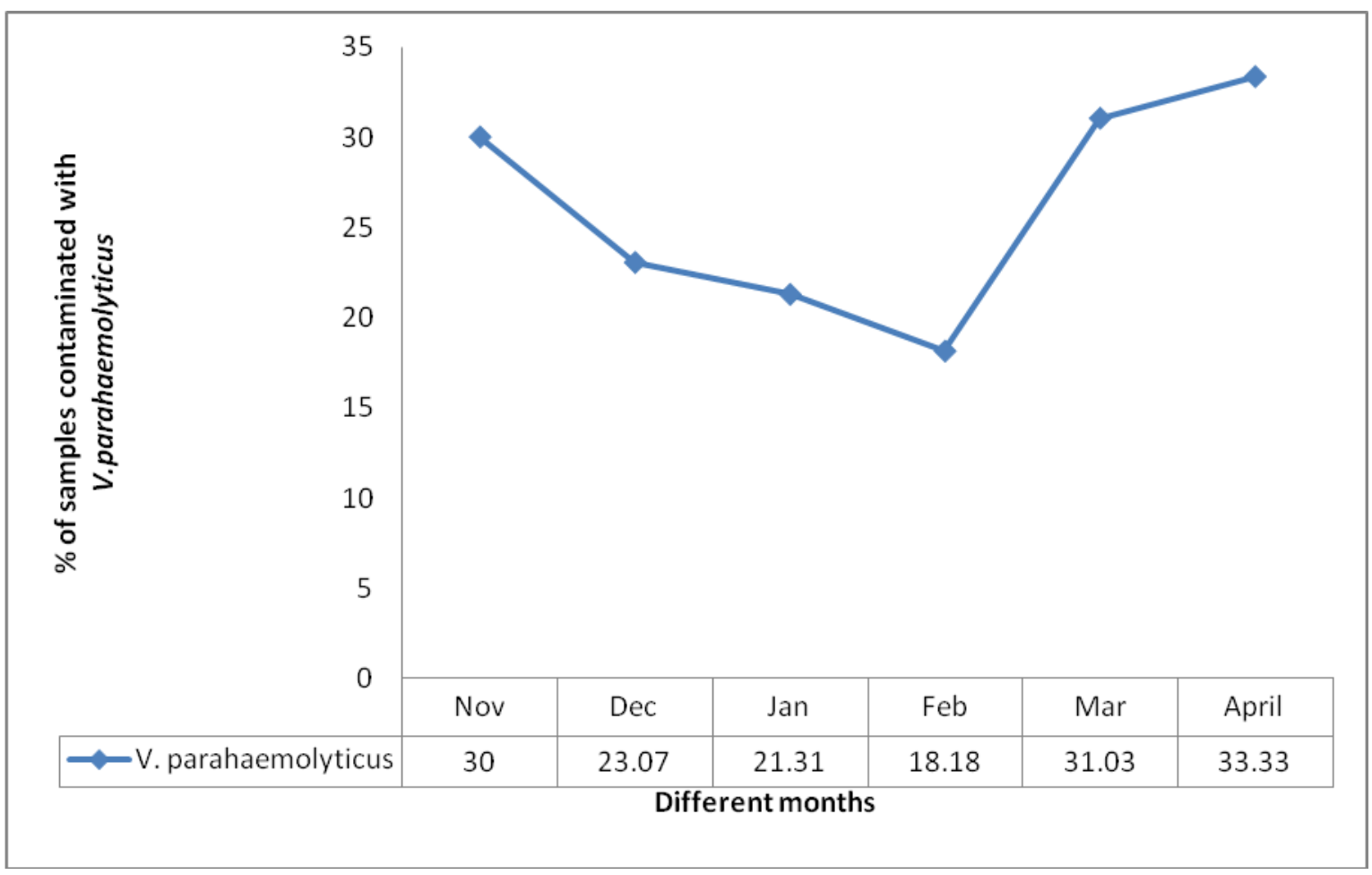

Cross- contamination with V.parahaemolyticus of other fish from contaminated seafood during preservation, transport and handling at market place are envisaged as major sources of $V$. parahaemolyticus infection in India. Besides seafood, freshwater fishes have also been studied for $V$. parahaemolyticus contamination. It is known that most strains of $V$. parahaemolyticus isolated from the environment or seafood are not pathogenic to humans. Only a small portion (1-5\%) of $V$. parahaemolyticus carrying the virulence genes encoding TDH and/or TRH can cause foodborne illnesses in humans (Hervio-Health et al., 2002). Therefore, consumer needs to increase awareness and to ensure that the fish and shrimps are cooked properly and maintain sanitary hygiene. The epidemiology of $V$. parahaemolyticus infection has changed in India with emergence of pandemic clone of O3: K6 serotype (Bisha et al., 2012). So, there is a high probability that the $V$. parahaemolyticus present fish and shellfish samples may pose risk to human health through under cooked food and cross contamination of other food items, household refrigerators used for fish and shellfish preservation and kitchen environment.

The epidemiology and transmission of infection associated with $V$. parahaemolyticus are more prominent in Kolkata, India than other parts of the globe because people never eat raw fish and usually prefer fresh water fish over marine fish. The fresh water fish might be contaminated with $V$. parahaemolyticus by marine fish at market and cross contamination are considered as tobe possible route of transmission in this setting (Nair et al., 2007). The higher incidence of $V$. parahaemolyticus in shellfish could be correlated with the ability of the bacterium to utilize chitin, abundantly available in the crustaceans. Moreover, shrimps are rich in free amino acid content, which serves as an excellent growth medium for the proliferation of this bacterium 
(Chakraborty et al., 2008). However, salt preference of bacterium was also reflected due to its association in shrimps and various marine fin fishes in the study.

Seasonal variations in occurrence of $V$. parahaemolyticus was studied and it was observed that $20.85 \%$ of finfish and shellfish collected during winter (December to February) were more contaminated by the bacterium in comparison to $31.45 \%$ of samples collected during summer months (November, March and April). The relationship between water temperature and prevalence of $V$. parahaemolyticus have been well studied by several researchers and higher occurrence was noticed during warmer seasons due to its proliferation in the aquatic environments (Nair et al., 1980; Sarkar et al., 1985; Daniels et al., 2000; CharlesHarnandez et al., 2006) which might have favored most of the outbreaks occur during warmer months. India being a tropical country is thus more prone to food-borne infections from the bacterium.

The present study has given an indication of hygienic and microbiological quality of fin fishes and shellfishes of domestic markets of West Bengal. Although, overall microbial load was within permissible limits, fishes were contaminated with $V$. parahaemolyticus raising food safety concern to the domestic consumers.

\section{Acknowledgements}

The authors are grateful to the Department of Zoology, Botany of Kalyani University, West Bengal to carry out the research.

\section{References}

Annual Report, 2014-15, Department of Fisheries, Aquaculture, Aquatic Resources and Fishing Harbours, Government of West Bengal.
Bharathi, L.P.A., Nair, S., Chandramohan, D. 1987. Occurrence and distribution of Vibrio parahaemolyticus and related organisms in the Arabian Sea. Mahasagar. 20:43-51.

Bisha, B., Simonson, J., Janes, M., Bauman, K., and Goodridge, L.D. (2012). Areview of the current status of cultural and rapid detection of Vibrio parahaemolyticus. Int. J. Food Sci. Tech. 47:855-899. doi: 10.1111/j.13652621.2012.02950.x

Chakraborty, R.D., Surendran, P.K. and Joseph, T.C. 2008. Isolation and characterization of Vibrio parahaemolyticus from seafoods along the southwest coast of India. W.J.Microbiol. and Biotechnol. 24: 2045-2054.

Charles-hernandez, G.L., Cifuentes, E. and Rothenberg, S.J. 2006. Environmental factors associated with the presence of Vibrio parahaemolyticus in sea products and the risk of food poisoning in communities bordering the Gulf of Mexico. J. Environ. Health Res. 5:7580.

Chiou C-S, Hsu S-Y, Chiu S-I, Wang T-K, Chao C-S (2000) Vibrio parahaemolyticus serovar $\mathrm{O} 3: \mathrm{K} 6$ as cause of unusually high incidence of food-borne disease outbreaks in Taiwan from 1996 to $1999 . \quad J$ ClinMicrobiol38:4621-4625

Chiou, A., Chen, L.-H. and Chen, S.-K. 1991. Foodborne illness in Taiwan, 19811989. Food. Aus. 43:70-71.

Chowdhury G, Ghosh S, Pazhani GP, Paul BK, Maji D, Mukhopadhyay AK, Ramamurthy T (2013). Isolation and characterization of pandemic and nonpandemic strains of Vibrio parahaemolyticus from an outbreak of diarrhea in North 24 Parganas, West Bengal. India. Foodborne Pathog. Dis. 10:338-342 
Cook, D. W., Leary, P. O’., Hunsucker, J. C., Sloan, E. M., Bowers, J. C., Blodgett, R. J., Depaola, A., 2002. Vibrio vulnificus and Vibrio parahaemolyticus in U. S. retail shell oysters: a national survey from June 1998 to July 1999. J. Food Prot. 65: 79-87.

Daniels, N. A., Ray, B., Easton, A., Marano, N., Kahn, E., Msshan, A. L, II., Del rosario, L., Baldwin, T., Kingsley, M. A., Puhr, N. D., Wells J. G., Angulo, F. G., 2001. Emergence of a new Vibrio parahaemolyticus serotype in raw oysters: a prevention quandary. J. Am. Med. Assoc 284:1541-1545.

Daniels, N.A., Mackinnon, L., Bishop, R., Altekruse, S., Ray, B. Hammond, R.M., Thompson, S., Wilson, S., Bean, N.H., Griffin, P.M. and Slutsker, L. 2000. Vibrio parahaemolyticus infections in the United States, 1973-1998. J. Infect. Dis. 181: 1661-1666.

Das, B., Manna, S.K., Sarkar, P. and Batabyal, K. (2009). Occurrence of Vibrio parahaemolyticus in different finfish and shellfish species. J. Food Safety, 29:118-125

Depaola, A., Kaysner, C. A., Bowers, J. C., Cook, D. W., 2000. Environmental investigations of Vibrio parahaemolyticus in oysters following outbreaks in Washington, Texas, and New York. (1997 and 1998). Appl. Environ. Microbiol. 66: 4649- 4654.

Food and Drug Administration (FDA). 2004. Bacteriological Analytical Manual on Line. 8th ed., Ch. 9. Revision A. 1998. AOAC International, Arlington, VA.

Gooch, J. A., Depaola, A., Bowers, J., Marshall, D. L. 2002. Growth and survival of Vibrio parahaemolyticus in post-harvest American Oyster. J. Food Prot. 65: 970-974.

Hervio-Health, D., Colwell, R.R., Derrien, A., Robert-Pillot, A., Fournier, J.M., Pommepuy, M., 2002. Occurrence of pathogenic vibrios in coastal areas of France. J. Applied Microbiol 92: 1123 1135.

ICMSF (International Commission on Microbiological Specification for Foods) 1986. Sampling plan for fish and shellfish In: Microorganisms in Foods 2. Sampling for microbiological analysis: Principles and specific applications. 2nd (ed.) pp 181196International Commission on Microbiological Specifications for Foods. http://www.icmsf.org/

Joseph, S.W., Colwell, R.R. and Kaper, J.B. 1983. Vibrio parahaemolyticus and related halophilic Vibrios. Crit. Rev.Microbiol.10:77-123.

Kanungo S., Sur D., Ali M., You Y. A., Pal D., Manna B., et al., (2012). Clinical, epidemiological, and spatial characteristics of Vibrio parahaemolyticus diarrhea and cholera in the urban slums of Kolkata, India. BMC Pub. Health 12:830 10.1186/1471-2458-12-830 [PMC free article] [PubMed] [Cross Ref]

Karunasagar, I., Nayak, B.B., Karunasagar, I. 1997. Rapid detection of Vibrio parahaemolyticus from fish by polymerase chain reaction (PCR). In Diseases in Asian aquaculture ( $\mathrm{T}$, Flegeland I.H, MacRae eds.) pp 119122 3rd edn. Asian Fisheries Society, Manila.

Kubota K, Iwasaki E, Inagaki S, Nokubo T, Sakurai Y, Komatsu M, Toyofuku H, Kasuga F, Angulo FJ, Morikawa K (2008). The human health burden of foodborne infections caused by Campylobacter, Salmonella and Vibrio parahaemolyticus in Miyagi Prefecture, Japan. Foodborne Pathog. Dis. 5:641648

Lalitha, M.K., Walter, N.M., Jesudasan, M. and Mathan, 1983. An outbreak of gastroenteritis due to Vibrio 
parahaemolyticus in Vellore. Indian $J$ Med Res78: 611-615.

Lozano-Leon. A., Torres, J., Osorio, C. R., Martinez-Urtaza., J. 2003. Identification of tdh- positive Vibrio parahaemolyticus from an outbreak associated with raw oyster consumption in Spain. FEMS Microbiol. Lett. 226:281-284

Ma C, Deng X, Ke C, He D, Liang Z, Li W, Ke B, Li B, Zhang Y, Ng L, Cui Z (2014). Epidemiology and etiology characteristics of foodborne outbreaks caused by Vibrio parahaemolyticus during 2008-2010 in Guangdong province, China. Foodborne Pathog. Dis. 11: 21-29.

Manna, S.K., Das, R. and Manna, C. 2008. Microbiological quality of finfish and shellfish with special reference to shiga toxin -producing Escherichia coli O157, J. Food. Sci. 73: 6, M283-286.

Matsumoto, C., Okuda, J., Ishibashi, M., Iwanaga, M., Garg, P., Ramamurthy, T., Wong, H., Depaola, A., Kim, Y. B., Albert, M. J., M. Nishibuchi, M. 2000. Pandemic spread of an O3: K6 clone of Vibrio parahaemolyticus and emergence of related strains of evidenced by arbitrarily primed PCR and toxRS sequence analysis. J.Clin.Microbiol. 38, 578-585.

Nair BG, Ramamurthy, T, Bhattacharya, S.K, Dutta, B, Takeda, Y and Sack. D.A. 2007. Global dissemination of Vibrio parahaemolyticus serotype O3:K6 and its serovariants. Clin. Microbiol. Rev. 20: 39-48.

Nair, G.B., Abraham, M. and Natarajan, R. 1980. Distribution of Vibrio parahaemolyticus in finfish harvested from Porto Novo (S. India) environs: A seasonal study. Can. J. Microbiol. 26:1264-1269.

Nayyarahamed, I., Karunasagar, I., Karunasagar, I. 1994. Microbiology of
Cultured Shrimps in India. FAO Fish. Rep. 514, 13-22 (Supplement).

Okuda, J., Ishibashi, M., Hayakawa, E., Nishino, T., Takeda, Y., Mukhopadhyay, A. K., Garg, S., Bhattacharya, S. K., Nair, G.B., Nishibuchi, M., 1997.Emergence of a unique O3:K6 clone of Vibrio parahaemolyticus in Calcutta, India, and isolation of strains from the same clonal group from southeast Asian travelers arriving in Japan. J.Clin.Microbio. 35:3150-3155.

Pal, D. and Das, N. 2010. Isolation, identification and molecular characterization of Vibrio parahaemolyticus from fish samples in Kolkata. Eur. Rev. Med. Pharmacol. Sci. 14: 545-549.

Pal, S.C., Sircar, B.K., Nair, G.B. and Deb, B.C. 1985. Epidemiology of bacteria diarrhoeal diseases in India with special reference to Vibrio parahaemolyticus infections. In Bacterial diarrhoeal diseases (Y. Takeda and T. Milwatani, eds.) pp. 65-73 KTK Scientific Publishers, Tokyo.

Pazhani G. P., Bhowmik S. K., Ghosh S., Guin S., Dutta S., Rajendran K., et al., (2014). Trends in the epidemiology of pandemic and non-pandemic strains of Vibrio parahaemolyticus isolated from diarrheal patients in Kolkata, India. PLoS ONE 8:2815 10.1371/journal. pntd.0002815

Sarkar, B.L., Nair, G.B., Banerjee, A.K and Pal, S.C. 1985. Seasonal distribution of Vibrio parahaemolyticus in freshwater environs and in association with freshwater fishes in Calcutta. Appl. Environ. Microbiol. 49:132-136.

Venkitanaranan, K.s. and Doyle, M.P. 2001. Food-borne infections and infestations. In Handbook of Nutrition and Food (C.D. Berdanier, eds.) pp 1135-1161. CRC Press, New York. 
Wong, H. C., Liu, S. H., Ku, L. W., Lee, I. Y., Wang, T. K., Lee, Y.S., Lee. C. L., Kuo, L. P., Shih, D.Y. C. 2000. Characterization of Vibrio parahaemolyticus isolates obtained from foodborne illness outbreaks during 1992 through 1995 in Taiwan. J. Food Prot.63: 900-906.

Yano Y., Hamano K., Satomi M., Tsutsui I., Ban M., Aue-Umneoy D. (2014). Prevalence and antimicrobial susceptibility of Vibrio species related to food safety isolated from shrimp cultured at inland ponds in Thailand. Food Control 38: 30-36. 10.1016/j.foodcont.2013.09.019

Zarei M., Borujeni M. P., Jamnejad A., Khezrzadeh M. (2012). Seasonal prevalence of Vibrio species in retail shrimps with an emphasis on Vibrio parahaemolyticus. Food Control 25: 107-109 10.1016/j.foodcont.2011.10. 024

\section{How to cite this article:}

Chandraval Dutta, Sanjib Kumar Manna, Ashis Kumar Panigrahi and Chandan Sengupta. 2018. Microbiological Quality of Fish and Shellfish, With Special Reference to Vibrio parahaemolyticus in Domestic Markets of West Bengal, India. Int.J.Curr.Microbiol.App.Sci. 7(10): 2772-2783. doi: https://doi.org/10.20546/ijcmas.2018.710.322 